\title{
Field Test of Grassed-Swale Performance in Removing Runoff Pollution
}

\author{
By Shaw L. Yu, ${ }^{1}$ Jan-Tai Kuo, ${ }^{2}$ Members, ASCE, Elizabeth A. Fassman, ${ }^{3}$ and Henry Pan $^{4}$
}

\begin{abstract}
The paper presents results of field tests, conducted in Taiwan and Virginia, of the pollutant removal efficiencies of grassed swales. Swales are a low-cost storm-water best management practice (BMP) that have been reported as a cost-effective method for controlling runoff pollution from land surfaces, especially highways and agricultural lands. The Virginia experiments tested a highway median swale, while the Taiwan experiments were conducted on an agricultural test farm. Average pollutant removal efficiencies reported for the test swales vary from 14 to $99 \%$ for total suspended solids (TSS), chemical oxygen demand (COD), total nitrogen (TN), and total phosphorus (TP). The wide range of performance results indicates the importance of such design parameters as length, longitudinal slope, and the presence of check dams. Minimum design guidelines for use of swales as a BMP are suggested.
\end{abstract}

\section{INTRODUCTION}

Grassed swales are increasingly being employed as a stormwater best management practice (BMP) for runoff quantity and quality control. The primary mechanisms for pollutant removal in swales are filtration by the vegetation, settling of particulates, and infiltration into the subsurface zone. As runoff travels through a swale, the vegetation reduces peak velocity while infiltration reduces flow volume. Attenuation of runoff flow promotes pollutant removal. In practice, check dams are sometimes placed in grassed swales to increase the detention time and to create a "mini-storage" effect.

Effectiveness of a swale as a BMP is therefore highly dependent on design characteristics such as length, longitudinal slope, and the presence of check dams. Each factor influences detention time, and hence treatment efficiency. Most studies show that long swales with gradual slopes are more effective at removing pollutants because of increased time for settling and physical sites for infiltration. (Kaighn and Yu 1996; Watershed Protection Techniques 1996; Patron 1998). Ponding of water behind check dams further enhances infiltration and settling by temporarily blocking the flow of water. Yu et al. (1994) presented a compilation of various studies' design guidelines, which recommended maximum 5\% longitudinal slope; 30 to $60 \mathrm{~m}$ length; $0.6 \mathrm{~m}$ bottom width; soil with high infiltration rate; dense, deep-rooted, flood-tolerant vegetation; and the inclusion of check dams.

Kaighn and Yu (1996) compared swales of equal length but having different slopes. One of the swales also contained a check dam. Results indicated that pollutant removal was impacted more by the presence of the check than by changes in slope. Yousef et al. (1985) also concluded that inclusion of check dams in swale design would have a significant impact on pollutant removal performance.

Pollutant removal efficiencies of swales reported in the literature covers a wide range. (Yousef et al. 1985; Kaighn and Yu 1996; Watershed Protection Techniques 1996; Barrett et al. 1998; Patron 1998). In general, swales show good perfor-

${ }^{1}$ Prof. of Civ. Engrg., Univ. of Virginia, Charlottesville, VA 22903.

${ }^{2}$ Prof., Dept. of Civ. Engrg. and Dir., Hydrotech Res. Inst., National Taiwan Univ., Taipei, Taiwan.

${ }^{3} \mathrm{PhD}$ Candidate, Dept. of Civ. Engrg., Univ. of Virginia, Charlottesville, VA.

${ }^{4}$ Former Graduate Student, Dept. of Civ. Engrg., National Taiwan Univ., Taipei, Taiwan.

Note. Discussion open until November 1, 2001. To extend the closing date one month, a written request must be filed with the ASCE Manager of Journals. The manuscript for this paper was submitted for review and possible publication on November 20, 2000; revised January 10, 2001 This paper is part of the Journal of Water Resources Planning and Management, Vol. 127, No. 3, May/June, 2001. C)ASCE, ISSN 07339496/01/0003-0168-0171/\$8.00 + \$.50 per page. Paper No. 22345. mance for removal of large particles, such as suspended solids (TSS); however, during intense storms, settled particles are potentially subject to resuspension, resulting in net export of pollutant. Export of pollutants has also been reported for nutrients. Investigation of total phosphorus (TP) and total nitrogen $(\mathrm{TN})$ removal for swales has indicated that the vegetation itself or fertilization might contribute to nutrient loads, particularly after mowing (Patron 1998).

Even though not all studies show positive results in terms of water quality improvement, swales are an attractive option for agencies such as departments of transportation since they are easily incorporated into the landscape, such as in highway medians. Minimal maintenance requirements include mowing and periodic inspection to assess vegetative health and fill in eroded paths. Swale construction costs are estimated at $\$ 5$ to $\$ 15$ per linear foot, which makes them a cost-effective option for storm-water management if performance is acceptable (Patron 1998). An analysis of design criteria, therefore, is warranted to render swale applications as effective as possible for storm-water management.

\section{CASE STUDIES}

\section{Site Descriptions}

\section{Taiwan}

The Taiwan experiments were conducted in 1997 on an agricultural experiment farm site of the National Taiwan University. The test swale (Fig. 1) was $30 \mathrm{~m}$ with a longitudinal slope of $1 \%$. A triangular weir was placed at the swale midpoint and outlet to facilitate flow measurement. The midpoint weir also served as a check dam. Synthetic runoff with prescribed pollutant concentrations and flow rate was fed to the swale from two 5-ton storage tanks. Tests were run with and without the midpoint check dam. Automatic and manual sampling techniques were employed in the experiments.

\section{Virginia}

Field testing of swales occurred in the summer of 1997 in Northern Virginia. The Goose Creek (heretofore referred to as GC) swale is located in the median of State Route 7, which is subject to an average daily traffic (ADT) of approximately 39,000 vehicles per day. Swale testing was performed during highway construction in the immediate drainage area, as shown in Fig. 2. The total length of the GC swale is $274.5 \mathrm{~m}$, with a $3 \%$ longitudinal slope and check dams located at 175 and $237.5 \mathrm{~m}$ from the swale inlet. Runoff that does not infiltrate into the swale is conveyed via storm sewer at the swale outlet for ultimate discharge to a scenic river. 


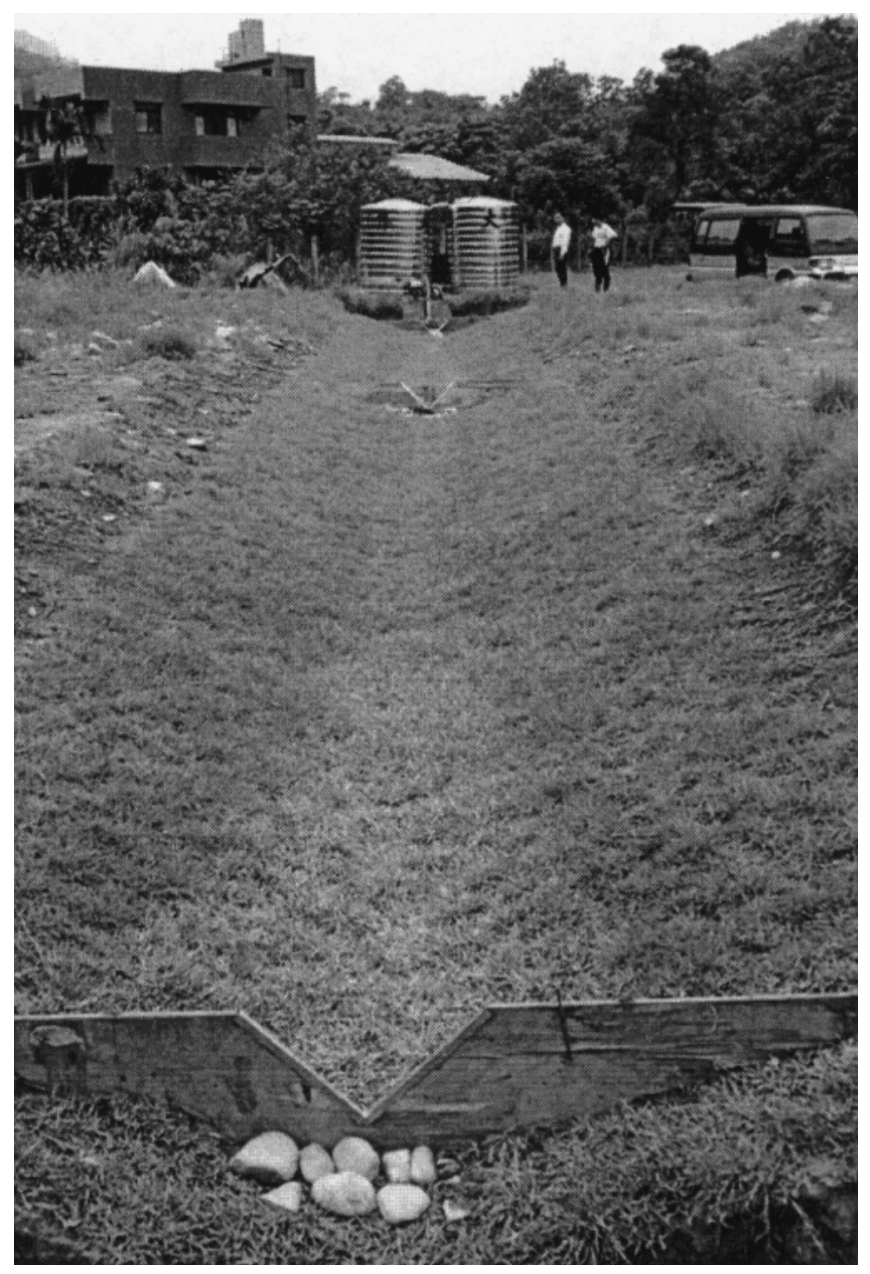

FIG. 1. $30 \mathrm{~m}$ Test Swale with 1 Check Dam at Taiwan Site

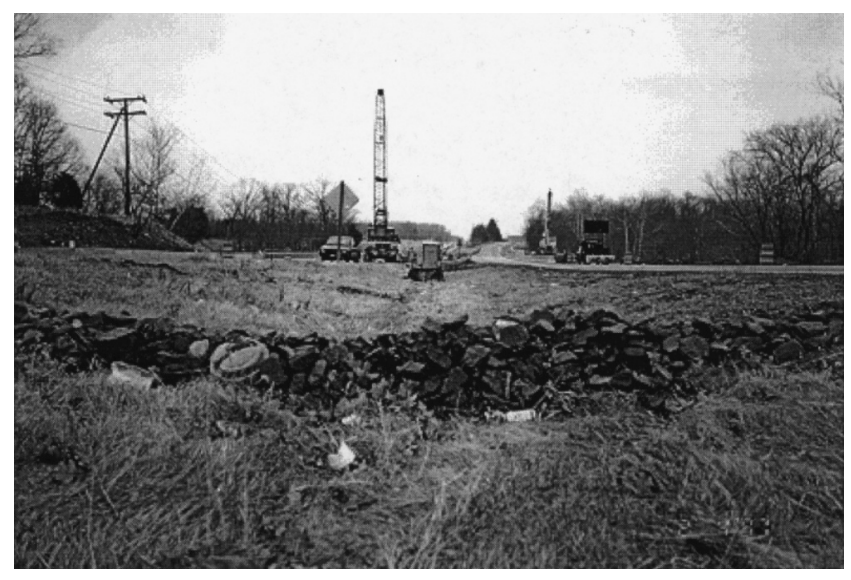

FIG. 2. Goose Creek Swale and Check Dam System

\section{Methodology}

\section{Taiwan}

As described above under "Site Descriptions," synthetic runoff with prescribed pollutant concentrations and flow rate was used in the swale experiments. Samples were taken manually and with automatic samplers at 5-10 min intervals. Each water sample was collected and analyzed individually in accordance with the QA/QC requirements specified by the Taiwan Environmental Protection Administration, which were based mainly on the Standard Methods for the Examination of Water and Waste Water.

\section{Virginia}

Site conditions permitted only manual sampling techniques. Storm samples were collected June 18, July 22, and August 4, 1997, at four locations along the swale - at the edge of pavement near the inlet, downstream of each check dam, and at the outlet. For each storm event monitored, sampling began after $0.25 \mathrm{~cm}(0.1$ in.) of rainfall accumulation, provided runoff was generated. For every $0.25 \mathrm{~cm}$ of accumulation thereafter, samples were taken at each location above where runoff occurred and the time was recorded. Samples were analyzed for TSS according to Standard Methods for the Examination of Water and Wastewater, 19th Edition, Method 2450D Total Suspended Solids Dried at $103-105^{\circ} \mathrm{C}$ (1995). Total phosphorus was analyzed according to Hach Method 8190, equivalent to U.S. EPA Method 365.2 and Standard Methods 4500-PB (5) and 45000-PE for wastewater.

Highway runoff flow into the swale was calculated using the rational formula, which is appropriate for small watersheds. Lateral flow into the swale was included in calculation of total runoff volume. Flow through the swale was determined using Manning's Equation, with the coefficient of roughness as prescribed from results of other swale studies (Yousef et al. 1985) and the continuity equation. It is important to note that since actual flow measurement was not possible, because of site limitations, calculation of flow through the swale does not account for runoff volume reduction due to infiltration. Therefore, pollutant mass removal for storms that were large enough to discharge runoff to the outlet is most likely underestimated. Mass removal was calculated according to flow weighting of sample concentration and the total flow through the swale. One hundred percent mass removal was assumed for storms that did not produce flow at the outlet (i.e., all runoff was infiltrated into the soil).

Precipitation data was collected on-site for most storms. Equipment failure during one storm resulted in inaccurate measurements. Precipitation data collected at Dulles International Airport (approximately $11.3 \mathrm{~km}$ from the site) was substituted for on-site data for this storm.

\section{RESULTS}

Results of field tests are found in Table 1. Mass balance calculations were calculated for all events where accurate flow measurements were possible. Four scenarios (TA, TB, TC, TD) were tested at the Taiwan site. TA and TC were conducted with inlet flows of $4.2 \times 10^{-3} \mathrm{~m}^{3} \mathrm{~s}^{-1}$ and $4.0 \times 10^{-3} \mathrm{~m}^{3} \mathrm{~s}^{-1}$, resulting in detention times of $7 \mathrm{~min}$ and $5.5 \mathrm{~min}$, respectively. TB and TD were conducted with inlet flows of $0.86 \times 10^{-3}$ $\mathrm{m}^{3} \mathrm{~s}^{-1}$ and $0.9 \times 10^{-3} \mathrm{~m}^{3} \mathrm{~s}^{-1}$ and detention times of $18 \mathrm{~min}$ and $10 \mathrm{~min}$, respectively. The Virginia data represent average pollutant removal efficiencies at the GC swale for three storms. The extensive length and presence of several check dams al-

TABLE 1. Pollutant Mass Removal for Test Swales: TSS, COD, TN, and TP

\begin{tabular}{llccccc}
\hline \hline & & \multirow{2}{*}{\begin{tabular}{c} 
Length \\
\cline { 3 - 6 }
\end{tabular}} & & \multicolumn{4}{c}{ Mass Removal (\%) } \\
\cline { 4 - 7 } & Experiment & $(\mathrm{m})$ & TSS & COD & TN & TP \\
\hline TA & check dam & 15 & 75.2 & 55.7 & 24.2 & 41.2 \\
& outlet & 30 & 69.7 & 62.9 & 20.9 & 76.9 \\
TB & check dam & 15 & 74.4 & 48.0 & 13.6 & 34.0 \\
& outlet & 30 & 86.3 & 45.6 & 23.1 & 58.1 \\
TC & outlet & 30 & 47.7 & 33.9 & 20.0 & 50.3 \\
TD & outlet & 30 & 67.2 & 42.7 & 13.8 & 28.8 \\
GC & upper & 238 & 29.7 & NT & NT & 73.4 \\
GC & lower & 99 & 97.2 & NT & NT & 96.8 \\
GC & entire swale & 274.5 & 94.0 & NT & NT & 98.6 \\
\hline
\end{tabular}

Note: "T" designates Taiwan Swale; "GC" designates Virginia Swale; $\mathrm{NT}=$ not tested. 
lowed for analysis of shorter segments of the swale, which reflect lengths more often reported in the literature. The upper GC swale was considered as the segment of the swale from the inlet to the second check dam for a total length of $238 \mathrm{~m}$. The lower GC swale was the segment from the first check dam to the swale outlet for a total length of $99 \mathrm{~m}$.

\section{DISCUSSION}

\section{Taiwan Swale}

Inspection of the table reveals several performance characteristics of the test swale. The most prominent swale feature that enhanced pollutant removal was the presence of the check dam in experiments TA and TB. For all pollutants tested, removal over the entire length of the swale was higher than for tests without the check dam (TC and TD). Comparison of tests performed at equal inflow rates (TA and TC, paired, and TB and TD, paired) indicates that mass removal at the check dam in most cases was higher than at the outlet for the no-check dam experiments. Flow retardation due to the check dam increases detention time, thereby enhancing sedimentation and contact time, and hence pollutant removal. For the low-flow case (TB and TD), detention time is almost doubled with the check dam. The check dam cases showed the greatest improvement TP reduction. Outlet removals less than check dam location removals are most likely due to resuspension of settled particles near the outlet or export of plant detritus, such as grass clippings. There was no significant difference in mass removal for COD between check dam and no-check dam cases.

Since the mass balance analysis incorporates flow volume, removal of pollutants can also indicate volume reduction. As runoff travels the length of the swale, runoff volume and pollutant concentration decreases because of infiltration and settling. Check dams enhance the amount of reduction.

\section{Virginia Swale}

Of the sections of the GC swale presented in table, the upper GC swale showed the poorest average pollutant removal efficiency. Edge of pavement samples collected at the site revealed high pollutant concentrations, particularly for TP. The upper section was subject to the greatest loads and, hence, one would expect reduced performance for this type of BMP. Short-circuiting of the system via lateral inflow may have also contributed to export of TP during the August storm and export of TSS during the June and August storms. The mass balance presented herein is a conservative estimate of performance since calculation of volume reduction was not possible. Therefore, actual export of pollutants during these storms may be less than as indicated, thereby reflecting overall improved performance of the system.

The lower section and the entire swale showed good performance as a stormwater BMP. The trend demonstrates the significance of swale length and the presence of check dams in terms of quantity and quality of improvements.

An important feature of the GC swale was its ability to infiltrate larger volumes of runoff, compared with other swales. The longer-than-average length and the presence of two check dams caused complete infiltration of runoff (and therefore $100 \%$ removal of pollutants) for storms with less than approximately $12.7 \mathrm{~mm}$ total precipitation. Complete infiltration of runoff was reported for two $30 \mathrm{~m}$ swales from storms with less than 5 and $7 \mathrm{~mm}$ total precipitation (Kaighn and Yu, 1996). Kercher et al. (1983) reported 99\% removal of pollutants measured for an extensive swale system, with only 3 out of 13 storms producing outflow. For geographic regions subject to frequent light rainfall, which results in long-dura- tion, low-intensity storms, swales can be highly effective for pollutant removal.

\section{SWALE DESIGN AND POLLUTANT REMOVAL}

Often regulations are written in terms of sediment and phosphorus removal. The data presented in this report were combined with results of eight studies found in the literature to demonstrate the theoretical relationship between swale design characteristics and pollutant removal (Urban Best Management Practices 1994, 1996; Yu et al. 1994; Kaighn and Yu 1996) Figs. 3 and 4 show TSS and TP removal with respect to swale length and slope. While a specific equation describing performance was prevented because of significant scatter of data points, combining field observation with engineering judgment leads to several conclusions worthy of note.

As previously stated, it is generally agreed that swale length and slope are important parameters leading to pollutant removal. Consideration of these design parameters is shown in Fig. 4 by a theoretical family of curves based on longitudinal slope. It is important to note that curves indicated on the figure are meant to show estimated trends; they are not meant as absolute relationships. More data is required to substantiate a definitive relationship. The figure does show, however, that in

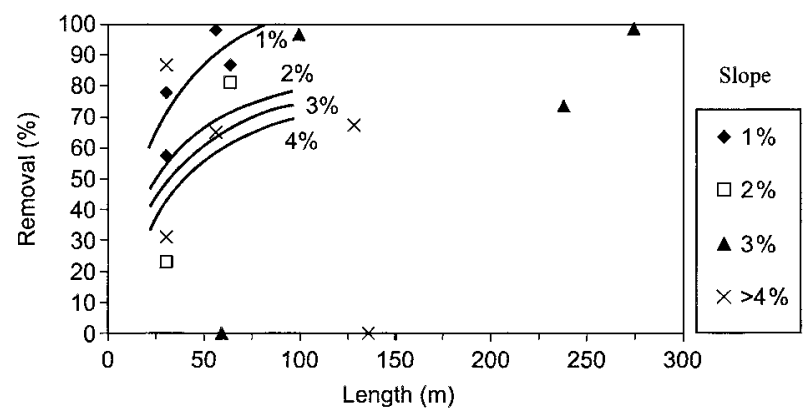

FIG. 3. Relationship between Swale Total Suspended Solids Removal Efficiency, Length, and Slope (Important: Curves Are Meant to Show Estimated Trends; They Are Not Absolute Relationships)

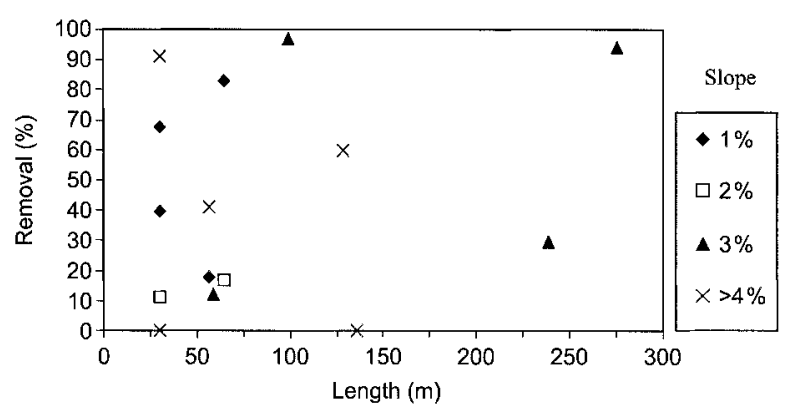

FIG. 4. Relationship between Swale Total Phosphorous Removal Efficiency, Length, and Slope

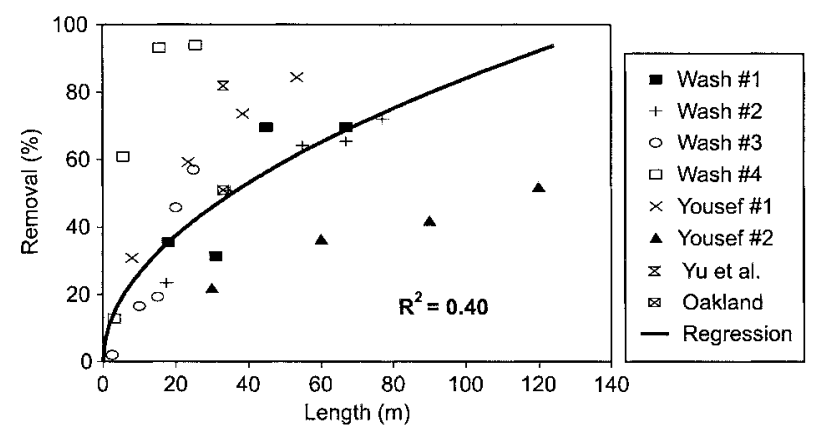

FIG. 5. Regression Curve Showing Relationship between Swale Length and Zinc Pollutant Removal (Kaighn and Yu 1996) 
addition to generally improved performance with increased length, swales with a more gradual slope reported better removal of suspended particles. The rate of improvement reaches a plateau when swales are longer than approximately $75 \mathrm{~m}$ regardless of slope. A relationship between swale length and zine ( $\mathrm{Zn})$ removal, as shown in Fig. 5 and presented by Kaighn and Yu (1996), also shows that the rate of increasing pollutant removal with length decreases after a sharp initial rise. The regression equation was reported as $R_{Z n}=8.302 L^{0.50}$, where $R_{Z N}$ represents zinc removal and $L$ is swale length. Significant scatter of data led to an $\mathrm{R}^{2}$ value of only 0.40 ; however, the figure shows a theoretical relationship similar to that found for TSS in this study.

Trends based on slope and length are not evident for removal of TP, as shown in Fig. 4. Swales generally are not considered efficient for removal of nutrients, due to the tendency to be effected by vegetation characteristics. The figure does demonstrate that increased swale length beyond approximately $75 \mathrm{~m}$ again does not result in a similar increase in pollutant reduction. Average TP mass removal for swales less than $75 \mathrm{~m}$ was approximately $42.3 \%$, whereas swales greater than $75 \mathrm{~m}$ long showed only increased mass removal by $4.5 \%$ on average.

Field test data for buffer strip performance have been used for detecting trends and developing design recommendations. For example, Desbonnet et al. (1994, after Jones, unpublished, 1997) compiled literature data for 35 buffer strips and found that removal efficiency for TSS, TP, and TN, in general, increases over buffer width but at a diminishing rate after approximately 10 to $50 \mathrm{~m}$, although the data were quite scattered. Also, Fan et al. (1998) used regression analysis to derive functional relationships between buffer strip pollutant removal efficiency and hydraulic loading rate and slope. The general form of the equation is as follows:

$$
R=A \times S^{b} \times\left(\frac{q}{L}\right)^{c}
$$

where $R$ is pollutant removal rate; $S$ the buffer strip slope; $q$ the flow rate across the strip; $L$ the buffer length; and $A, b, c$ are regression coefficients. Since the key parameters-i.e., slope, length, and flow rate-are also applicable to swales, similar equations could be derived for the latter. The growing interest in implementation of infiltration techniques for stormwater management gives rise to a demand for effective design criteria. Further research in the application of swales for removing runoff pollution can lead to empirical relationships such as described by (1) for use by water quality professionals.

\section{CONCLUSIONS}

1. Properly engineered grassed swales can be an effective storm-water BMP, particularly for areas subject to lowintensity storms.

2. Swales should be a minimum of $75 \mathrm{~m}$ in length and have a maximum $3 \%$ longitudinal slope.

3. The presence of check dams generally improves swale performance.

\section{ACKNOWLEDGMENTS}

The writers would like to thank Estela Patron for her assistance with this project.

\section{REFERENCES}

Barrett, M. E., Walsh, P. M., Malina, J. F., Jr., and Charbeneau, R. J. (1998). "Performance of vegetative controls for treating highway runoff." J. Envir. Engrg., ASCE, 124(11), 1121-1128.

Fan, J. C., Chang, J. K., and Cheng, K. S. (1998). "A study on nonpoint source pollution and best management practices in agricultural areas." Report to Taiwan Environmental Protection Admin., Dept. of Agric. Engrg., National Taiwan University, Taipei, Taiwan (in Chinese).

Kaighn, R. J., Jr., and Yu, S. L. (1996). "Testing of roadside vegetation for highway runoff pollutant removal." Transp. Res. Rec. 1523: Highway and Facility Design; Soils, Geology, and Foundations, Transportation Research Board, National Research Council, Washington, D.C.

Kercher, W. C., Jr., Landon, J. C., and Masserelli, R. (1983). "Grassy swales prove cost-effective for water pollution control." Public Works, 114(4), 53-54.

Patron, E. J. (1998). "Grassed swales as runoff BMPs." Master's thesis, University of Virginia, Charlottesville, Va.

Yousef, Y. A., Wanielista, M. P., and Harper, H. H. (1985). "Removal of highway contaminants by roadside swales." Transp. Res. Rec. 1017: Surface Drainage and Highway Runoff Pollutants, Transportation Research Board, National Research Council, Washington, D.C., 62-68.

Yu, S. L., Kaighn, R. J., Jr., and Liao, S. (1994). "Testing of best management practices for controlling highway runoff. Phase II final report." FHWA/VA-94-R21, Virginia Transportation Research Council, Richmond, Va.

Urban Best Management Practices. (1994). "Performance of grassed swales along East Coast highways." Watershed Protection Techniques, $1(3), 122-123$.

Urban Best Management Practices. (1996). "Ditches or biological filter? Classifying the pollutant removal performance of open channels." Watershed Protection Techniques, 2(2), 379-383. 